\title{
Contamination of heavy metals in birds from Embalse La Florida (San Luis, Argentina)
}

\author{
Fabricio Damián Cid, ${ }^{a b c}$ Claudia Gatica-Sosa, ${ }^{a b}$ Rosa Isabel Antón ${ }^{d}$ and Enrique Caviedes-Vidal ${ }^{* a b c}$
}

Received 30th March 2009, Accepted 4th August 2009

First published as an Advance Article on the web 11th September 2009

DOI: 10.1039/b906227k

Embalse La Florida is an artificial lake located in midwestern Argentina's San Luis province. It provides drinking water to $\sim 70 \%$ of the province's human population and $\sim 20 \%$ of the province is irrigated with water from the reservoir. The presence of heavy metals in Embalse La Florida's water has previously been reported. Nevertheless, no information about the levels of these contaminants in birds is available for this region. The aim of this study, therefore, is to (1) establish baseline data on lead $(\mathrm{Pb})$ and cadmium (Cd) levels in birds from Embalse La Florida, (2) assess metal accumulation patterns between organs and bird species, and (3) evaluate the potential risk that these heavy metals pose for the local avifauna. We measured $\mathrm{Pb}$ and $\mathrm{Cd}$ in bone, pectoralis muscle, liver, gonad, and brain of three bird species representative of the Embalse La Florida ecosystem: Podiceps major (Great Grebe),

Phalacrocorax brasilianus (Neotropic Cormorant), both of which are piscivorous, and Pitangus sulphuratus (Great Kiskadee), which is omnivorous. We also measured both heavy metals in Great Grebe eggs. $\mathrm{Pb}$ and $\mathrm{Cd}$ were detected in all of the tissues we assayed, and $\mathrm{Pb}$ concentrations were significantly higher than those for $\mathrm{Cd}$ in all tissues. The patterns of $\mathrm{Pb}$ and $\mathrm{Cd}$ accumulation differed between tissues, however. In general, gonads had the highest concentrations of $\mathrm{Pb}$ while $\mathrm{Cd}$ tended to accumulate in the liver. An interspecific analysis revealed that the omnivorous species had higher levels of both metals in bone, liver, and brain compared to both piscivorous species. There were no differences in $\mathrm{Pb}$ and $\mathrm{Cd}$ concentrations between males and females. The highest liver level of $\mathrm{Pb}(4.69$ ppm wet weight) detected in Great Kiskadee, was comparable to those associated with toxic effects in birds, and $\mathrm{Pb}$ concentrations found in the liver of two females and two males ( 2.07 to $2.32 \mathrm{ppm}$ wet weight) were also similar to those that could be physiologically detrimental in other species. In all birds assayed, Cd levels in liver tissue were lower than those typically shown to be harmful. Our results indicate that Great Kiskadees are highly polluted by $\mathrm{Pb}$ and their exposure to this contaminant exceeds the level reported to trigger adverse effects. This is the first study to assay heavy metals in birds from midwest Argentina and provides a starting point for studies examining the impact that these metals have on both wildlife and humans in the region.

${ }^{a}$ Laboratorio de Biología "Prof. E. Caviedes Codelia", Facultad de Ciencias Humanas, Universidad Nacional de San Luis, Chacabuco 917, 5700 San Luis, Argentina.E-mail: enrique.caviedes@gmail.com; fabricio. cid@gmail.com; Tel: +54-02652-423789 int.129

${ }^{b}$ Laboratory of Integrative Biology, IMIBIO-SL, CONICET, Chacabuco 917, 5700 San Luis, Argentina

'Área de Biología, Departamento de Bioquímica y Ciencias Biológicas, Facultad de Química, Bioquímica y Farmacia, Universidad Nacional de San Luis, Chacabuco 917, 5700 San Luis, Argentina

'Área de Química Analitica, Departamento de Química, Facultad de Química Bioquímica y Farmacia, Universidad Nacional de San Luis, Chacabuco 917, 5700 San Luis, Argentina

\section{Introduction}

Heavy metals occur naturally in all ecosystems, but industrial activities and urbanization have greatly increased their concentration in the environment. Recently, concern has grown over the impact that heavy metal contamination may have on both human and wildlife food resources. ${ }^{1,2}$ For this reason, monitoring heavy metals in ecosystems is one important step in assessing and preventing health risks to both wildlife and humans.

\section{Environmental impact}

Heavy metals are associated with deleterious effects on fauna and humans. Thus, monitoring heavy metals in the environment is mandatory to establish the magnitude of the contamination, anticipate risks of planned actions, take decisions about public health or environmental protection, establish research priorities, and provide scientific basis for regulatory actions. In this paper, we report for the first time levels of lead and cadmium in birds of the Midwest of Argentina and discuss the potential risk of the observed contamination for the avifauna of this region. This heavy metal monitoring was intended as a starting point for future studies and as a base for researchers and land managers to initiate policies to remediate or reduce the effects of the contamination. 
Lead $(\mathrm{Pb})$ and cadmium $(\mathrm{Cd})$, both nutritionally nonessential metals, are relatively persistent pollutants in nature. They accumulate in organisms and are biomagnified in the food chain. ${ }^{3-6}$ The teratogenic, carcinogenic, and likely mutagenic properties of both metals are responsible for a variety of acute and chronic toxic effects. ${ }^{3,4,7,8}$

Recently, heavy metal contamination in both the water and sediments of our study lake, Embalse La Florida (Fig. 1), have been measured. Embalse La Florida is located in the San Luis province of midwestern Argentina $\left(66^{\circ} \mathrm{W}, 33^{\circ} 07^{\prime} \mathrm{S}\right)$. In addition to providing drinking water to roughly $70 \%$ of this province's human population, approximately $20 \%$ of the agricultural land in this province is irrigated with water from Embalse La Florida. ${ }^{9}$ The quality of the water in Embalse La Florida, however, seems poor. That is, several sectors of the reservoir have $\mathrm{Pb}$ and $\mathrm{Cd}$ concentrations above those permitted for drinking water $(\mathrm{Pb}$ range: $24.41-103.56 \mathrm{ppb}$; Cd range: $0.29-1.05 \mathrm{ppb}$ ) which have probably resulted from human activities. ${ }^{10}$ The health of the Embalse La Florida reservoir and ecosystem are of interest because the area is home to a rich diversity of wildlife and is, as previously mentioned, an important source of water for humans, animals and irrigation in the region. Furthermore, having been constructed on the Río Quinto river, the water in Embalse La Florida also impacts downstream areas, including those in the provinces of Buenos Aires, Santa Fé, Cordoba, and La Pampa. Despite the high levels of $\mathrm{Pb}$ and $\mathrm{Cd}$ contamination and the importance of this aquatic ecosystem, no studies have measured heavy metals in animals or humans that utilize resources from Embalse La Florida. Therefore, our work is intended to (1) establish baseline concentration data of these heavy metals in organisms associated with the reservoir, (2) examine the distribution of $\mathrm{Pb}$ and $\mathrm{Cd}$ between different tissues, (3) compare the $\mathrm{Cd}$ and $\mathrm{Pb}$ burden in species belonging to different positions in

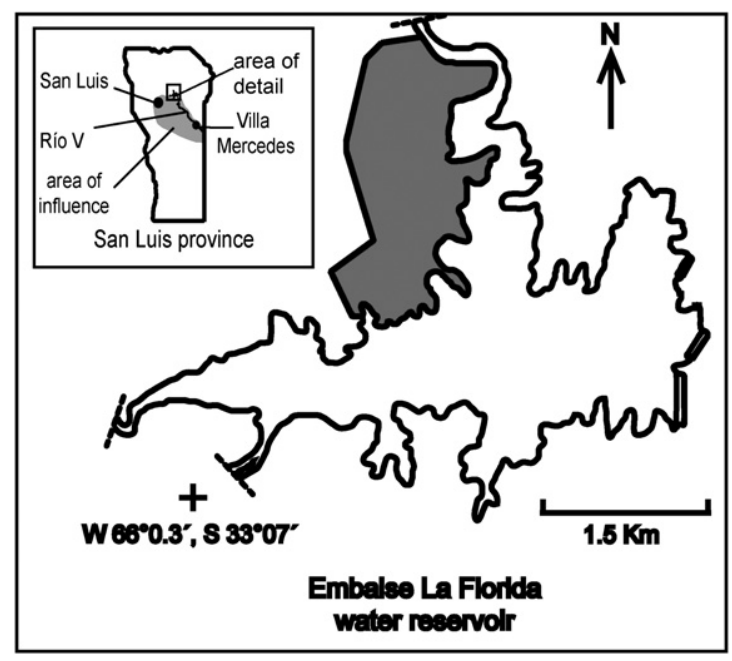

Fig. 1 Geographic location of the Embalse La Florida water reservoir. This artificial lake provides drinkable water to around $70 \%$ of the human population of San Luis province and irrigation water to approximately one fifth of this province's territory (gray-shaded area in the San Luis province map). The gray area in the map represents the natural reserve "Reserva Natural La Florida" created in 1992, along the northern shoreline of the Embalse La Florida water reservoir, to protect the natural flora and fauna. the food chain, and (4) consider the potential for adverse physiological effects based on the $\mathrm{Pb}$ and $\mathrm{Cd}$ concentrations we measured.

We chose birds as bioindicators for this study because they are easy to identify, sample, and track and the contaminant levels in their tissues integrate temporal and spatial exposure. ${ }^{11}$ Additionally, birds at the top of food chains often accumulate high levels of pollutants in their tissues and are particularly susceptible to physiological disruption. ${ }^{12,13}$ Studies in birds report that $\mathrm{Cd}$ is associated with behavior and metabolism alterations, gonad and kidney damage, egg laying inhibition, anemia, and growth retardation. ${ }^{14,15}$ With respect to $\mathrm{Pb}$, it has been shown to negatively effect most body systems. ${ }^{4,16-18}$ For instance, in birds, $\mathrm{Pb}$ impairs survival, growth, locomotor and thermoregulatory capacity, development, learning, and metabolism. ${ }^{14,19-22}$

Pollutant accumulation occurs when organisms are unable to degrade and/or eliminate compounds at the same rate at which they are incorporated. Following absorption in the intestinal tract, metals may accumulate in body tissues or be excreted. ${ }^{1,11,23}$ Additionally, reproductive females may also transfer metals into their eggs. ${ }^{24-27}$

The three bird species we used in this study exhibit different degrees of piscivory. Neotropic Cormorant (Phalacrocorax brasilianus) and Great Grebe (Podiceps major) are specialized piscivores; Great Kiskadees (Pitangus sulphuratus) are omnivorous, but also predate on fish. ${ }^{9}$ All three species are at the top or near to the top of the food chain in the Embalse La Florida ecosystem.

\section{Materials and methods}

\section{Collection of material}

During the austral spring of 2002, we captured 15 adult birds (>one year): six Great Kiskadees (three of each sex), seven Neotropic Cormorants (four males, three females), and two Great Grebe males at Embalse La Florida (Fig. 1). We also collected three Great Grebe eggs. All captures were performed under authorization of the Government of the Province of San Luis, Ministry of Human and Social Development, Program of Planning and Environmental Management (Resolution No. 027, 01/11/2005).

Each animal was examined carefully for external abnormalities and measured (body mass, body length, wingspan, tarsus length, and wing length). Table 1 shows the sample list and biometry data. The birds were then stored individually in plastic bags, refrigerated, and sent immediately to the laboratory. Upon arriving at the laboratory, we weighed the animals (Table 1), opened their abdominal cavities, and inspected the external appearance of internal organs. During these dissections we sexed the birds by examining gonads.

Samples of the liver, muscle, bone, gonad, and brain were excised, and an aliquot of each tissue was used for quantifying $\mathrm{Pb}$ and $\mathrm{Cd}$ burden. In Great Grebe eggs, $\mathrm{Pb}$ and $\mathrm{Cd}$ were determined in both eggshells and content.

\section{Solvents and chemicals}

Nitric acid 60\% (Merck, Ultrapur), hydrogen peroxide $31 \%$ (Merck, Ultrapur), perchloric acid 70\% (Merck, Suprapur), magnesium matrix modifier $50 \mathrm{ml}(\mathrm{Mg})=10.0 \pm 0.2 \mathrm{~g} / \mathrm{l}$ in 
Table 1 Biometry of bird (length and weight values are mean \pm SD) captured from Embalse La Florida

\begin{tabular}{|c|c|c|c|c|c|}
\hline \multirow{2}{*}{$\begin{array}{l} \\
\text { Species } \\
\text { Sex } \\
\text { Number }\end{array}$} & \multirow{5}{*}{$\begin{array}{l}\text { Great Kisk } \\
\text { sulphuratus } \\
\frac{\text { male }}{3}\end{array}$} & itangus & \multicolumn{2}{|c|}{$\begin{array}{l}\text { Neotropic Cormorant }{ }^{a} \text { (Phalacrocorax } \\
\text { brasilianus) }\end{array}$} & \multirow{2}{*}{$\begin{array}{l}\text { Great Grebe (Podiceps major) } \\
\text { male } \\
2\end{array}$} \\
\hline & & female & male & female & \\
\hline body mass/g & & $58.9 \pm 6.0$ & $1393.8 \pm 104.9$ & $1355.8 \pm 36.5$ & $1325.5 \pm 46.2$ \\
\hline tarsus length/mm & & $23.0 \pm 2.9$ & $46.5 \pm 1.4$ & $46.5 \pm 3.7$ & $60.9 \pm 0.9$ \\
\hline wing length $/ \mathrm{cm}$ & & $17.8 \pm 0.7$ & $53.4 \pm 1.4$ & $49.3 \pm 0.9$ & $33.3 \pm 5.8$ \\
\hline
\end{tabular}

${ }^{a}$ For Great Kiskadee and Neotropic Cormorant, no significant statistical difference was found in biometry measures between males and females (Mann-Whitney U Test, $\mathrm{P} \leq 0.05$ ).

nitric acid 15\% (Merck), Palladium matrix modifier $50 \mathrm{ml}$ $(\mathrm{Pd})=10.0 \pm 0.2 \mathrm{~g} / \mathrm{l}$ in nitric acid 15\% (Merck). Stock standard solution of Cd Merck of $1003 \pm 2 \mathrm{mg} / \mathrm{l}$, lot OC 105824, traceable to SRM from NIST Cd $\left(\mathrm{NO}_{3}\right)_{2}$ in $\mathrm{HNO}_{3} 0.5 \mathrm{~mol} / \mathrm{l}$. Stock standard solution of $\mathrm{Pb}$ Merck of $1000 \pm 2 \mathrm{mg} / \mathrm{l}$, lot OC186400, traceable to SRM from NIST $\mathrm{Pb}\left(\mathrm{NO}_{3}\right)_{2}$ in $\mathrm{HNO}_{3}$ $0.5 \mathrm{~mol} / \mathrm{l}$. All water used in this study was deionized (Milli-Q Element). All plastic-ware and glassware were acid-washed in 1:10 nitric acid (analytical grade) followed by a thorough rinsing with water.

\section{Analytical procedure}

Wet samples were weighed and then dried at $90-100{ }^{\circ} \mathrm{C}$ for about $24 \mathrm{~h}$ until constant mass. Dry samples were reweighed and subsequently digested in a 2:1 (v/v) mixture of nitric and perchloric acid. The sample (about $0.1 \mathrm{~g}$ ), was placed in a digestion tube and treated with $2 \mathrm{ml}$ of concentrated nitric acid. Next, it was heated progressively at $150{ }^{\circ} \mathrm{C}$ for $1 \mathrm{~h}$, after which $1 \mathrm{ml}$ of perchloric acid was added and it was heated at $200^{\circ} \mathrm{C}$. Lastly, we added $1 \mathrm{ml}$ of oxygenated water. The digestion was finalized when no fumes were observed and the mixture was pale and without sediments. After decomposition, the solution was transferred quantitatively to a $5 \mathrm{ml}$ volumetric flask. Method 200.9 revision 1.2 4/91 (Determinations of trace elements by stabilized temperature graphite furnace atomic absorption spectrometry) was used to determine $\mathrm{Cd}$ and $\mathrm{Pb}$ in samples in a Perkin-Elmer graphite furnace atomic absorption spectrometry model AAnalyst 200 (GFAAS - GF 900).

Metal concentrations are expressed as ppm wet weight (ppm ww). To facilitate comparisons, dry weight concentrations (ppm dw) are also reported in Table 2 and Table 3.

\section{Quality assurance}

Validation was carried out on a synthetic sample (cow liver homogenate) with the addition of $\mathrm{Cd}$ and $\mathrm{Pb}$ standard solutions traceable to SRM from NIST, following method 200.9 revision $1.24 / 91$ protocol. Metal concentrations of reference material and recoveries are shown in Table 4. Blanks, reference material and spiked samples were always run with samples. Spike recoveries accepted ranged from $95 \%$ to $105 \%$.

Additionally, an inter-laboratory comparison with the ECOCHEM S.A. Laboratory (San Luis, Argentina), accredited for ISO 9001, ISO 14000, and in process of accreditation for IRAM 301 and ISO 17025 was carried out. The results for this intercomparison exercise were acceptable and are shown in Table 4.

\section{Statistical analyses}

All statistical analyses were made using the concentrations expressed as ppm ww.

The parametric tests were performed on log-transformed data to satisfy the normality and homogeneity of the variance. The normality of the data was tested using the Shapiro-Wilk W test ${ }^{28}$

Table 2 Mean \pm standard error of the mean and range of $\mathrm{Pb}$ concentrations (ppm, ww: wet weight and dw: dry weight) in the tissues of $\mathrm{N}$ birds from Embalse La Florida

\begin{tabular}{|c|c|c|c|c|c|c|}
\hline \multirow[b]{2}{*}{ Tissue } & \multicolumn{2}{|c|}{$\begin{array}{l}\text { Great Kiskadee (Pitangus } \\
\text { sulphuratus) }(\mathrm{N}=6)\end{array}$} & \multicolumn{2}{|c|}{$\begin{array}{l}\text { Neotropic Cormorant } \\
\text { (Phalacrocorax brasilianus) }(\mathrm{N}=7)\end{array}$} & \multicolumn{2}{|c|}{$\begin{array}{l}\text { Great Grebe (Podiceps major) } \\
(\mathrm{N}=2)\end{array}$} \\
\hline & (ppm ww) & $(p p m d w)$ & (ppm ww) & $(\mathrm{ppm} \mathrm{dw})$ & (ppm ww) & (ppm dw) \\
\hline Muscle & $\begin{array}{l}1.76 \pm 0.50 \\
\left(0.45 \_3.26\right)\end{array}$ & $\begin{array}{l}3.81 \pm 0.81 \\
\left(1.39 \_6.19\right)\end{array}$ & $\begin{array}{l}0.77 \pm 0.12 \\
\left(0.40 \_1.15\right)\end{array}$ & $\begin{array}{l}2.17 \pm 0.38 \\
\left(1.08 \_3.30\right)\end{array}$ & $\begin{array}{l}1.74 \pm 1.41 \\
\left(0.32 \_3.15\right)\end{array}$ & $\begin{array}{l}3.88 \pm 2.95 \\
\left(0.93 \_6.83\right)\end{array}$ \\
\hline Bone & $\begin{array}{l}3.31 \pm 0.60 \\
\left(1.89 \_5.39\right)\end{array}$ & $\begin{array}{l}3.60 \pm 0.63 \\
\left(2.07 \_5.86\right)\end{array}$ & $\begin{array}{l}1.19 \pm 0.30 \\
\left(0.39 \_2.08\right)\end{array}$ & $\begin{array}{l}1.33 \pm 0.34 \\
\left(0.46 \_2.34\right)\end{array}$ & $\begin{array}{l}0.75 \pm 0.54 \\
\left(0.22 \_1.29\right)\end{array}$ & $\begin{array}{l}0.85 \pm 0.60 \\
\left(0.26 \_1.45\right)\end{array}$ \\
\hline Gonad & $\begin{array}{l}5.02 \pm 0.80 \\
\left(2.30 \_7.87\right)\end{array}$ & $\begin{array}{l}8.05 \pm 0.72 \\
\left(4.85 \_9.86\right)\end{array}$ & $\begin{array}{l}3.57 \pm 0.68 \\
\left(1.37 \_6.19\right)\end{array}$ & $\begin{array}{l}9.68 \pm 1.48 \\
\left(4.16 \_14.39\right)\end{array}$ & $\begin{array}{l}1.56 \pm 0.85 \\
\left(0.71 \_2.40\right)\end{array}$ & $\begin{array}{l}5.81 \pm 2.23 \\
\left(3.59 \_8.04\right)\end{array}$ \\
\hline Brain & $\begin{array}{l}5.16 \pm 2.44 \\
\left(0.93 \_16.23\right)\end{array}$ & $\begin{array}{l}11.15 \pm 5.04 \\
\left(2.44 \_33.36\right)\end{array}$ & $\begin{array}{l}0.44 \pm 0.05 \\
\left(0.23 \_0.57\right)\end{array}$ & $\begin{array}{l}1.76 \pm 0.17 \\
\left(0.95 \_2.29\right)\end{array}$ & $\begin{array}{l}1.27 \pm 0.43 \\
\left(0.85 \_1.70\right)\end{array}$ & $\begin{array}{l}5.34 \pm 1.84 \\
\left(3.50 \_7.18\right)\end{array}$ \\
\hline
\end{tabular}


Table 3 Mean \pm standard error of the mean and range of Cd concentrations (ppm, ww: wet weight and dw: dry weight) in tissues of $\mathrm{N}$ birds from Embalse La Florida

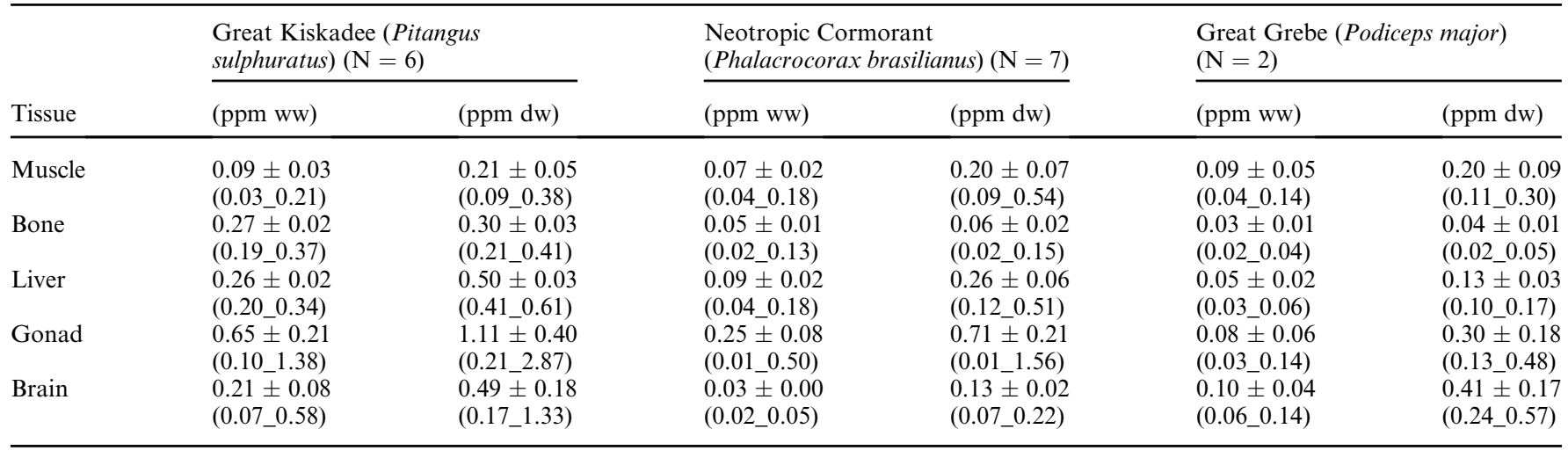

Table 4 Validation was carried out on a synthetic sample (cow liver homogenate) with the addition of Cd and Pb standard solutions traceable to SRM from NIST, following method 200.9 revision 1.2 4/91 protocol. Additionally an inter-laboratory comparison exercise with ECOCHEM S.A. Laboratory (San Luis, Argentina) was conducted using an inductively coupled plasma-optical emission spectrometer (ICP-OES), Perkin Elmer Optima-5300 DV ICP-OES equipped with a SeaSpray concentric nebulizer and cyclonic spray chamber. Certified, mean observed and external laboratory ( \pm 1 S.D.) values in ppm per dry weight and percent recoveries are shown

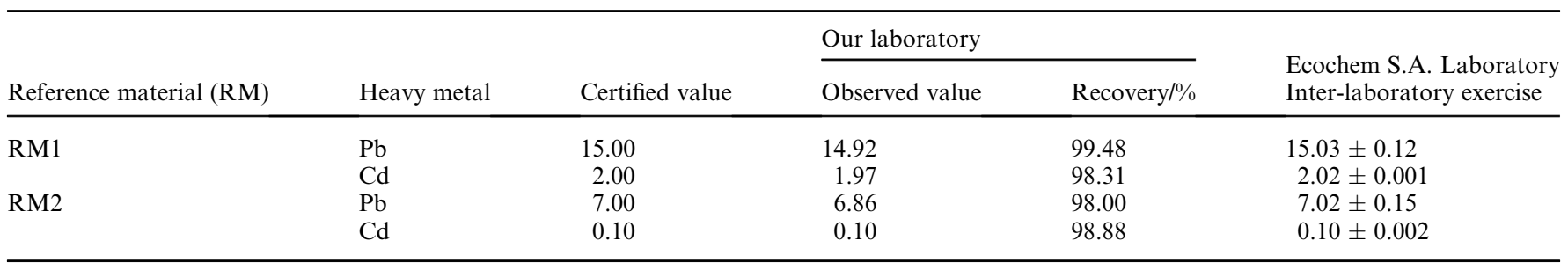

and the homogeneity of the variance using the Levene test. ${ }^{29}$ All nonparametric tests were made on nontransformed data. Pearson's product moment correlation ( $r$ ) was used to analyze the relationship between $\mathrm{Pb}$ and $\mathrm{Cd}$ for each tissue and to evaluate the correlation of each metal between different tissues. This test was not applied for Great Grebe tissue or egg values, on account of the small size of the sample (Table 1). We used repeated measures analysis of variance (RM-ANOVA) with Fisher's Least Significant Difference (LSD) post hoc tests to check for differences between tissue concentration of $\mathrm{Pb}$ and $\mathrm{Cd}$. A paired Student's t-test was also used to compare the $\mathrm{Cd}$ and $\mathrm{Pb}$ concentration in each tissue. Student's t-test ${ }^{30}$ for independent samples was applied to check the difference in the metal concentration between piscivores and the omnivore. To compare the metal concentration between sexes, we utilized the U-Man Whitney test. ${ }^{31}$ For all statistical tests, we used $\alpha=0.05$ as the level of significance.

\section{Results}

Levels of $\mathrm{Pb}$ and $\mathrm{Cd}$ were detected in all the tissues we assayed (Table 2 and Table 3). Pb and $\mathrm{Cd}$ were not correlated (Pearson correlation, $\mathrm{P}>0.05)$, and $\mathrm{Pb}$ concentrations were significantly higher (7.5-24.4 times higher; Table 2) than Cd concentrations in all of the tissues we examined (Paired Student's t-test, $\mathrm{P}<0.05$ ).

There was no correlation between $\mathrm{Pb}$ and $\mathrm{Cd}$ concentrations in the internal tissues of Great Kiskadees and Neotropic Cormorants (Pearson correlation, $\mathrm{P}>0.05$, Great Kiskadee: $\mathrm{N}=6$,
Neotropic Cormorant: $\mathrm{N}=7$ ). $\mathrm{Pb}$ concentrations differed among tissues in Neotropic Cormorants (RM-ANOVA $\mathrm{F}_{4,20}=$ 13.58, $\mathrm{P}<0.001$ ), but not in Great Kiskadees (RM-ANOVA $\left.\mathrm{F}_{4,20}=2.30, \mathrm{P}=0.093\right)$. Gonads of Neotropic Cormorants exhibited significantly higher $\mathrm{Pb}$ concentrations than those detected in muscle $(\mathrm{P}<0.001)$, bone $(\mathrm{P}<0.001)$, liver $(\mathrm{P}<0.001)$, and brain tissues $(\mathrm{P}<0.001) ; \mathrm{Pb}$ levels were higher in bone compared to brain tissue $(\mathrm{P}<0.05)$.

Cd concentrations were positively correlated between the liver and muscle of Great Kiskadees (Pearson correlation, $\mathrm{N}=6, \mathrm{r}=$ $0.93, \mathrm{P}<0.05)$ and between muscle, bone, and liver tissues of Neotropic Cormorants (Pearson correlation, muscle vs. bone: $\mathrm{N}=7, \mathrm{r}=0.78, \mathrm{P}=0.04$; muscle vs. liver: $\mathrm{N}=7, \mathrm{r}=0.80, \mathrm{P}=$ 0.03 ; bone $v s$. liver: $\mathrm{N}=7, \mathrm{r}=0.83, \mathrm{P}=0.02)$. Cd concentrations varied between tissues of Great Kiskadees (RM-ANOVA $F_{4,20}=$ $6.17, \mathrm{P}=0.002$ ) and Neotropic Cormorants (RM-ANOVA $\left.\mathrm{F}_{4,20}=3.31, \mathrm{P}=0.027\right)$. Cd concentrations of muscle were significantly lower compared to the concentrations of bone, liver, and gonad tissues in Great Kiskadees (Fisher's LSD: muscle vs. bone: $\mathrm{P}=0.004$; muscle $v s$. liver: $\mathrm{P}=0.005$; muscle $v$. gonad: $\mathrm{P}<$ 0.001). Also, the brain had a lower Cd concentration than gonads in Great Kiskadees (Fisher's LSD: $\mathrm{P}=0.013$ ). In the Neotropic Cormorant, $\mathrm{Cd}$ levels of liver tissue were significantly higher than the concentrations detected in brain tissue (Fisher's LSD: $\mathrm{P}=$ 0.031). Gonad and liver tissue had similar concentrations of $\mathrm{Cd}$, and these concentrations were higher than those detected in both brain and bone (Fisher's LSD: gonad vs. brain: $\mathbf{P}=0.003$; gonad vs. bone: $\mathrm{P}=0.019)$. 

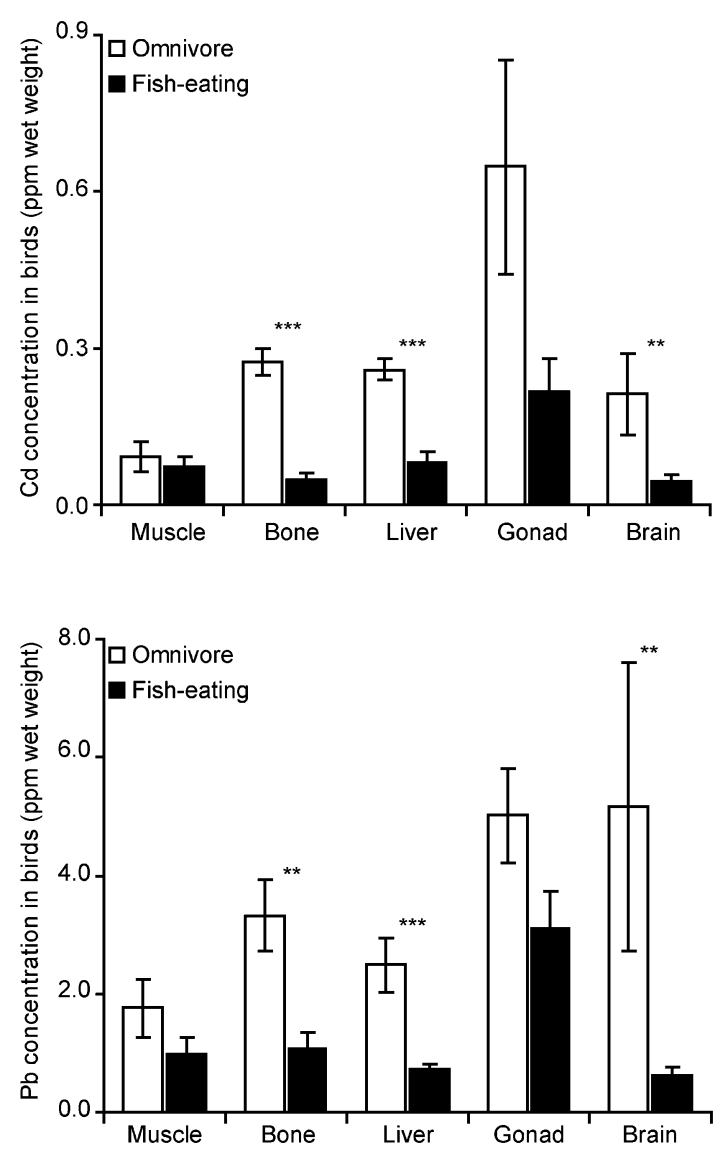

Fig. 2 Comparison of metal burdens ( $m e a n \pm 1$ SEM, ppm ww) between two piscivorous and one omnivorous bird of Embalse La Florida. Asterisks denote a significant difference between dietary categories for the same metal (Student's t-test, ${ }^{*} \mathrm{P}<0.05,{ }^{* *} \mathrm{P}<0.01$ and ${ }^{* * *} \mathrm{P}<0.001$ ).

The $\mathrm{Pb}$ and $\mathrm{Cd}$ concentrations found in bone, liver, and brain tissue were significantly higher in Great Kiskadees (an omnivore) compared to Neotropic Cormorants and Great Grebes (both piscivorous; Student's t-test; Cd-bone: $\mathrm{t}=6.96$, degrees of freedom $(\mathrm{df})=13, \mathrm{P}<0.05$; Cd-liver: $\mathrm{t}=5.07, \mathrm{df}=13, \mathrm{P}<0.05$; Cd-brain: $\mathrm{t}=$ 4.06, $\mathrm{df}=13, \mathrm{P}<0.05$; $\mathrm{Pb}$-bone: $\mathrm{t}=3.54, \mathrm{df}=13, \mathrm{P}<0.05$; Pb-liver: $\mathrm{t}=5.92, \mathrm{df}=13, \mathrm{P}<0.05 ;$ Pb-brain: $\mathrm{t}=4.01, \mathrm{df}=13, \mathrm{P}<0.05$; Fig. 2).

$\mathrm{Pb}$ and $\mathrm{Cd}$ were detected in all Great Grebe eggshell and egg content samples we examined. Nonstatistical comparisons due to our small sample size showed similar or greater Cd concentrations in eggshell (0.253 ppm ww, $0.266 \mathrm{ppm} \mathrm{dw})$ and in egg content $(0.100 \mathrm{ppm}$ ww, $0.389 \mathrm{ppm} \mathrm{dw})$ than the concentrations found in tissues of adult Great Grebe (Table 3). Pb concentrations in eggshell $(0.650 \mathrm{ppm} w \mathrm{w}, 0.684 \mathrm{ppm} \mathrm{dw})$ were greater than that in egg content $(0.056 \mathrm{ppm} w \mathrm{ww}, 0.217 \mathrm{ppm} \mathrm{dw})$ and similar to that found in bone of Great Grebe adults (Table 2).

Concentrations of $\mathrm{Pb}$ and $\mathrm{Cd}$ in bone, liver, muscle, and brain did not differ between sexes of Neotropic Cormorants and Great Kiskadees (Mann-Whitney U Test: P > 0.05).

\section{Discussion}

\section{$\mathrm{Pb}$ and $\mathrm{Cd}$ distribution in internal tissues}

For all examined tissues of the three species studied, the $\mathrm{Pb}$ concentration was higher than $\mathrm{Cd}$ (Table 2 and Table 3). This difference may reflect the environmental abundance of each metal as $\mathrm{Pb}$ levels in the water of Embalse La Florida are 100 times greater than Cd levels (Cd range: 0.29 to $1.05 \mathrm{ppb}$ and $\mathrm{Pb}$ range: 24.41 to $103.56 \mathrm{ppb}) .^{32}$

The high concentration of $\mathrm{Pb}$ in the water of Embalse $\mathrm{La}$ Florida may be the result of human activities. For instance, boats navigating the reservoir have combusted leaded fuel for $\sim 45$ years and leaded plumbs (fishing weights) have been used by anglers for roughly 55 years. ${ }^{33}$

$\mathrm{Pb}$ distribution patterns were different between species. In the Neotropic Cormorant, $\mathrm{Pb}$ was more concentrated in the gonad compared to liver, bone, muscle, and brain tissue. The pattern of $\mathrm{Pb}$ distribution in tissues, however, is not consistent among species or between sexes. For example, Dauwe et al. ${ }^{34}$ found that $\mathrm{Pb}$ levels were higher in bone and liver compared to ovary, muscle, and brain tissue of female Great Tits (Parus major). In House Sparrows (Passer domesticus), Dauwe et al. ${ }^{34}$ reported that $\mathrm{Pb}$ concentrations were high in liver, intermediate in bone, and low in both muscle and brain tissue. Van Wyk et al. ${ }^{2}$ detected in five African Whitebacked Vultures (Pseudogyps africanus) high levels of $\mathrm{Pb}$ in bone, intermediate levels in liver and muscle, and low concentrations in brain tissue. These same authors also reported high $\mathrm{Pb}$ concentrations in muscle tissue compared to brain tissue of Lappetfaced Vultures (Torgos tracheliotos) and Cape Griffons (Gyps coprotheres), ${ }^{2}$ which is similar to the pattern we found in Neotropic Cormorants.

In the Neotropic Cormorant, we detected the highest $\mathrm{Cd}$ burden in gonad and liver tissue, indicating that these tissues were the dominant targets for $\mathrm{Cd}$ accumulation. This tendency for $\mathrm{Cd}$ to accumulate in gonad and liver has previously been reported for other species. Dauwe et al. ${ }^{34}$ found that $\mathrm{Cd}$ concentrations in Great Tit (Parus major) females were high in liver and ovary and low in muscle, bone, and brain tissue. Saeki et $a l .{ }^{35}$ found levels of $\mathrm{Cd}$ that were higher in liver compared to those in the muscle, bone, and brain tissue of Common Cormorants (Phalacrocorax carbo). Other studies have also reported high concentrations of $\mathrm{Cd}$ in liver and low concentrations in the muscle, bone, and brain of birds. ${ }^{36,37}$ This is likely because the principal avian $\mathrm{Cd}$ detoxification system is in the liver. ${ }^{37}$ The smaller mean concentration of $\mathrm{Cd}$ we detected in the brain of Neotropic Cormorants is coincident with others studies. ${ }^{34,38}$ It is also known that a blood-brain barrier prevents the transference of $\mathrm{Cd}$ to brain tissue. ${ }^{35}$

\section{Comparison between dietary habits}

A difference was found for both metals between omnivores and fish-eating birds. Bioaccumulation up the food chain has been reported for a wide variety of pollutants in many different environments. ${ }^{13,39}$ Our findings of $\mathrm{Pb}$ and $\mathrm{Cd}$ in omnivores and fish-eating birds did not reflect the trophic position in the food chain. These differences in contamination between the omnivorous and the fish-eating birds may be explained by the different metabolism of these compounds, a different diet, and/or forage in different regions (migrations). Unfortunately, even though differences in metabolism may be a factor that may explain dissimilar contamination patterns, it is impossible to infer anything due to the scarcity of studies carried out on wild birds ${ }^{40}$ and the lack of them analyzing the specific presence of $\mathrm{Cd}$ and $\mathrm{Pb}$ 
in the species we studied. Differential use of resources may explain why the omnivorous species differed from the piscivorous birds in the accumulation patterns of both $\mathrm{Pb}$ and $\mathrm{Cd}$. Generally, birds that are at the top of the food chain and that predate on large fishes accumulate higher amounts of pollutants than those that are at a lower position and/or eat smaller fishes. ${ }^{41}$ However, our findings do not offer support for this phenomenon. A possible explanation is that, in the Embalse La Florida ecosystem, Neotropic Cormorants predate on Argentine Silversides (Odontesthes bonariensis). These fish are approximately $10 \mathrm{~cm}$ in length (0-1 year old) and have a relatively short exposure time to $\mathrm{Cd}$ and $\mathrm{Pb}$, which suggests that they may have low concentrations of the heavy metals. Alternatively, it is possible that Great Kiskadees, the omnivorous species in our study, have a higher level of heavy metals than piscivorous birds because the Great Kiskadees predate on a wide range of aquatic and terrestrial items (e.g., fruits, seeds, invertebrates, amphibians, fish) and the heavy metal concentrations for these prey items is not known. Similarly, Burger ${ }^{41}$ found high levels of $\mathrm{Pb}$ in eggs of herring gulls; this omnivore species ate invertebrates, fish, and garbage. Blus et al. ${ }^{42}$ found high $\mathrm{Pb}$ levels in tissues of nestling American Robins (Turdus migratorius) from northern Idaho, indicating that terrestrial invertebrates probably had high $\mathrm{Pb}$ concentrations. Also, species that forage on the ground may have a higher risk, ingesting $\mathrm{Pb}$ from the soil. ${ }^{43} \mathrm{~Pb}$ concentrations have been shown to be greater in soil relative to water in some ecosystems when $\mathrm{Cd}$ concentrations were approximately equal in both the terrestrial and aquatic areas. ${ }^{44}$ In Embalse La Florida, high $\mathrm{Pb}$ levels in the tissues of Great Kiskadees suggest that terrestrial invertebrates and plants probably contain elevated $\mathrm{Pb}$ concentrations. Another potential explanation for the observed differences between omnivorous species and the piscivorous birds may be the migratory behavior of some species. Preliminary data that we have collected indicate that the over-wintering population of Neotropic Cormorants decreases to approximately $12.5 \%$ of the spring-summer population in the Embalse La Florida ecosystem. Consequently, it is possible that Neotropic Cormorants reside in a less polluted aquatic ecosystem for at least a portion of the year, which may diminish their contamination load.

\section{$\mathrm{Pb}$ and $\mathrm{Cd}$ in eggs}

Although $\mathrm{Pb}$ and $\mathrm{Cd}$ are thought to accumulate less in eggs when compared to the internal tissues of birds,,$^{11,45,46}$ we found $\mathrm{Pb}$ and $\mathrm{Cd}$ levels in Great Grebe eggs to be on par with several tissues in adult birds. In agreement with this finding, Swaileh and Sansur ${ }^{36}$ reported similar magnitudes of $\mathrm{Pb}$ and $\mathrm{Cd}$ in eggs and some tissues of House Sparrow (Passer domesticus). They found $\mathrm{Pb}$ concentrations (ppm dw) of 3.3 and 1.6 in eggshell and egg contents, respectively, and 2.4 in brain, 1.9 in heart, and 1.4 in muscle tissue; $\mathrm{Cd}$ concentration ( $\mathrm{ppm} \mathrm{dw}$ ) was 0.02 in egg contents, 0.01 in eggshell, 0.02 in brain, 0.02 in feathers, 0.02 in heart, and 0.03 in both lung and muscle tissue.

Other authors have measured $\mathrm{Pb}$ and $\mathrm{Cd}$ in bird eggs, and the levels they report were similar in magnitude to what we found here. Gochfeld ${ }^{12}$ found that mean Cd levels in eggs of Herring Gulls (Larus argentatus) from New York Bight ranged from 123 to $400(\mathrm{ng} / \mathrm{g} \mathrm{ww})$ and mean $\mathrm{Pb}$ levels were in the 934 to 4150 range (ng/g ww). In other studies, the levels of $\mathrm{Pb}$ and/or $\mathrm{Cd}$ were lower than our results here. For instance, Goutner et al. ${ }^{14}$ found that mean $\mathrm{Pb}$ levels ranged from 7 to 83 (ppb ww) and mean $\mathrm{Cd}$ levels were between 3 and 7 (ppb ww) in the eggs of four bird species from the wetlands in Greece. Additionally, when Burger et al. ${ }^{47}$ analyzed the temporal variation (from 1996 to 2001) of metals in eggs of Scrub-Jays from south-central Florida, they found $\mathrm{Cd}$ concentrations between 2 and 3 (ppb, $\mathrm{dw}$ ) and $\mathrm{Pb}$ levels that ranged from 3 to 22 (ppb, dw).

Goutner et al. ${ }^{14}$ stated that eggs can be useful tools for environmental biomonitoring, especially in environments with high concentrations of these metals. The eggshell, provided that it is collected after chicks hatch, can be used as a noninvasive tool for monitoring levels of these metals in the environment. Our results of similar concentrations of $\mathrm{Pb}$ and $\mathrm{Cd}$ in eggs and in some tissues of Great Grebes gives support to Goutner et al. statement, ${ }^{14}$ though we must caution readers that we analyzed a limited number of samples ( 3 eggs and 2 adult individuals).

\section{Inter-sex comparison}

Metals found in eggs may come from the mobilization of mother tissues and/or from the diet. ${ }^{25}$ In either case, transference of metals to eggs could lessen the burden on females and generate differences between the sexes in contamination load. Unfortunately, we did not have the opportunity to collect female Great Grebes to test this hypothesis since the literature is controversial about this issue. ${ }^{24,36,37,48-50}$ In the other two species we studied, Neotropic Cormorant and Great Kiskadee, we did not find differences in $\mathrm{Pb}$ or $\mathrm{Cd}$ levels between males and females.

\section{Potential adverse effects}

Our hazard evaluation for birds of Embalse La Florida is based on a comparison of the levels found in this study and those previously reported as being harmful to other avian species, because there are no species-specific toxicity assays available for the studied species or reports of $\mathrm{Pb}$ and $\mathrm{Cd}$ dynamics in the studied ecosystem. To our knowledge, the level of contamination with these metals in birds of Argentina has not been studied before. Therefore this is the first attempt to assay heavy metals in birds from midwestern Argentina and provides a starting point for studies examining the impact these metals have on both the wildlife and humans in the region.

Lead. Quantification of $\mathrm{Pb}$ in the liver is routinely used to determine the poisoning in birds. A Pb liver burden in birds higher than $10 \mathrm{ppm}$ ww has been associated with clinical signs of $\mathrm{Pb}$ poisoning; first signs of this intoxication, however, occur at lower concentrations. ${ }^{51}$ Liver $\mathrm{Pb}$ concentrations associated with adverse effects in birds have been classified in the following categories: no effects (NE), physiological effects (PE, e.g., deltaaminolevulinic acid dehydratase (ALAD) depression, etc., without overt signs of poisoning), toxic effects (TE, overt signs of poisoning, including muscle wasting, weakness, anemia, abnormal movement coordination), and severe toxic effects (STE, mortality and morbidity). ${ }^{51,52}$ For Waterfowl, these liver $\mathrm{Pb}$ concentrations (ppm ww) are: $\mathrm{NE}<2$, PE 2-6, TE 6-15, and $\mathrm{STE}>15 ;{ }^{51,53}$ for birds of prey: $\mathrm{NE}<2, \mathrm{PE} 2-4, \mathrm{TE}>3$, and $\mathrm{STE}$ 
$>$ 5; for Doves and Pigeons: NE <2, PE 2-6, TE $>6$, and STE $>$ 20; and for Quail and Pheasant: NE > 2, PE 2-6, TE > 6, and STE $>15 .^{51,52,54}$

$\mathrm{Pb}$ concentrations in the liver of Great Kiskadees were within the range reported for passerines from areas thought to be unpolluted to areas that are known to be severely contaminated ${ }^{36,42,43,55,56}$ Considering the above classification, the highest liver level of $\mathrm{Pb}$ (4.69 ppm ww) we detected in Great Kiskadees was comparable to those associated with toxic effects in birds, and $\mathrm{Pb}$ concentrations found in the liver of two females and two males (2.07 to $2.32 \mathrm{ppm}$ ww) were also similar to those that could generate negative physiological effects in others species. Also, these values were higher than those liver levels $(<1.0-2.9$ ppm ww) used as controls in some studies on $\mathrm{Pb}$ in passerines. ${ }^{43}$ Mean $\mathrm{Pb}$ liver levels found in Great Kiskadees were comparable or greater to those mean levels reported in livers of Song Sparrows (Genus species) from the $\mathrm{Pb}$ contaminated floodplains in the Coeur d'Alene River Basin, Idaho, and this species had a mean ALAD inhibition of $51 \%$ compared to that in its reference site. ${ }^{55}$ The maximum level of $\mathrm{Pb}$ in the liver of Great Kiskadees was similar to those (mean values) reported in the liver of Northern Cardinals (Cardinalis cardinalis) from the $\mathrm{Pb}$, $\mathrm{Zn}$, and $\mathrm{Cd}$ contaminated areas of the Tri State Mining District (Oklahoma, Kansas and Missouri). ${ }^{56}$ In these contaminated areas, a $60 \%$ inhibition of ALAD activity was observed when compared to the reference site. ${ }^{56}$ In Neotropic Cormorants and Great Grebes, the $\mathrm{Pb}$ liver concentrations we detected were greater than those previously published for conspecifics or congenerics (Phalacrocorax and Podiceps) from the other parts of the world; $37,57,58,59$ these concentrations were, however, lower than the risk levels mentioned earlier. The elevated $\mathrm{Pb}$ levels found in the tissues of Great Kiskadee (liver, gonad, bone, and brain) and in some tissues (gonad and brain) of Neotropic Cormorants and Great Grebes examined in this study suggest that $\mathrm{Pb}$ is a problem in Embalse La Florida and needs to be closely monitored.

Cadmium. Cd has both teratogenic and carcinogenic properties, and is thought to be deleterious to wildlife. ${ }^{3}$ Concentrations of $\mathrm{Cd}$ in liver (Table 3 ) of all birds in this study were below the levels assumed as a background ( $<3 \mathrm{ppm} \mathrm{dw}$ ) for freshwater waterfowls. ${ }^{60,61}$ These levels are far lower than those concentrations considered adverse in other bird species. In birds, poisoning may occur when $\mathrm{Cd}$ concentrations in the liver reach approximately 40 ppm ww. ${ }^{56}$ Based on the concentrations we detected in tissues of birds from Embalse La Florida, it seems unlikely that these species are at risk from $\mathrm{Cd}$ exposure. Additional work is needed, however, to support this conclusion. The low $\mathrm{Cd}$ levels we report in bird tissues here may be explained by the mean concentration range of this metal $(0.29-1.05 \mathrm{ppb})$ in the water of Embalse La Florida, ${ }^{10,32}$ which is below that reported (>10 ppb) to produce adverse effects (mortality, reduced growth rates, reduction or inhibition of reproduction) on freshwater biota. ${ }^{3}$

Additionally, all species assayed are resident to the study area $^{62}$ and are present there in high numbers, are nonmigratory sedentary birds, not endangered, and have a wide geographic distribution in Argentina and the Americas. ${ }^{63}$ These characteristics make these species suitable candidates for use as biomonitors for metal pollution.

\section{Conclusions}

We found that birds from the Embalse La Florida ecosystem are exposed to high $\mathrm{Pb}$ and low $\mathrm{Cd}$ contamination. These metals have been detected in all examined sample tissues of three bird species.

The omnivorous species (Great Kiskadee) exhibited higher $\mathrm{Pb}$ and $\mathrm{Cd}$ burdens in bone, liver, and brain than the piscivorous ones (Neotropic Cormorant and Great Grebe). Interestingly, however, Great Kiskadees are positioned at a lower trophic level than both the Neotropic Cormorant and Great Grebe.

No difference was found between males and females for $\mathrm{Cd}$ or $\mathrm{Pb}$.

Differences were observed in the distribution patterns of $\mathrm{Pb}$ and $\mathrm{Cd}$ between tissues belonging to the same species. Gonad tissues were found to contain the highest $\mathrm{Pb}$ levels compared with other tissues. High concentrations of $\mathrm{Cd}$ were detected in the liver and gonad tissues of Neotropic Cormorants and Great Kiskadees.

$\mathrm{Pb}$ contaminations detected in the liver of Great Kiskadees of Embalse La Florida were greater than those levels that produce adverse effects in other avian species.

Based on our findings, additional work is needed to examine how $\mathrm{Pb}$ and $\mathrm{Cd}$ levels in the Embalse La Florida ecosystem change over time and the possible impact these environmental pollutants are having on both the wildlife and humans that rely on this ecosystem.

\section{Acknowledgements}

The authors thank Briardo Llorente Ruiz, Manuel Gontero Fourcade, and Diego González for helping to capture and process birds, and Club Náutico y Pesca La Florida (San Luis) for housing the team in their installations. We are also deeply grateful to Dr. Bradley Hartman Bakken for his thorough and critical reading of the manuscript and two anonymous reviewers for their helpful comments. FONCYT 7-7488 and UNSL-CyT 22Q751 grants to EC-V funded the study. During the research Fabricio Damián Cid (FDC) held a doctoral fellowship from FONCYT; this study was performed as a partial fulfilment of FDC's doctoral dissertation defended at the PROBIOL UNC Doctorate program. At present, FDC holds a postdoctoral fellowship from CONICET.

\section{References}

1 J. Burger and M. Gochfeld, Arch. Environ. Contam. Toxicol., 1997, 32, 217-221.

2 E. van Wyk, F. H. van der Bank, G. H. Verdoorn and D. Hofmann, S. Afr. J. Anim. Sci., 2001, 31, 57-63.

3 R. Eisler, Cadmium hazards to fish, wildlife, and invertebrates: $A$ synoptic review, Contaminant Hazard Reviews Report 2, USGS Patuxent Wildlife Research Center, U.S. 1985.

4 R. Eisler, Lead hazards to fish, wildlife, and invertebrates: A synoptic review, Contaminant Hazard Reviews Report 14, USGS Patuxent Wildlife Research Center, U.S. Fish and Wildlife Service. 1988.

5 S. H. Prankel, R. M. Nixon and C. J. C. Phillips, Environ. Res., 2005, 97, 348-358.

6 Q. W. Yang, W. S. Shu, J. W. Qiu, H. B. Wang and C. Y. Lan, Environ. Int., 2004, 30, 883-889.

7 E. Rojas, L. A. Herrera, L. A. Poirier and P. Ostrosky-Wegman, Mutat. Res., Genet. Toxicol. Environ. Mutagen., 1999, 443, 157-181. 
8 M. P. Waalkes, J. Liu, R. A. Goyer and B. A. Diwan, Cancer Res., 2004, 64, 7766-7772.

9 F. D. Cid, R. I. Anton and E. Caviedes-Vidal, Sci. Total Environ., 2007, 385, 86-96.

10 R. I. Antón, personal communication.

11 K. H. Ek, G. M. Morrison, P. Lindberg and S. Rauch, Arch. Environ. Contam. Toxicol., 2004, 47, 259.

12 M. Gochfeld, Arch. Environ. Contam. Toxicol., 1997, 33, 63-70.

13 C. H. Walker, S. P. Hopkin, R. M. Sibly and D. B. Peakall, Principles of Ecotoxicology, Taylor and Francis, New York, 2ed, 2001, pp. 309.

14 V. Goutner, I. Papagiannis and V. Kalfakakou, Sci. Total Environ., 2001, 267, 169-176.

15 O. Hogstad, Sci. Total Environ., 1996, 183, 187-194.

16 I. J. Fisher, D. J. Pain and V. G. Thomas, Biol. Conserv., 2006, 131, $421-432$.

17 L. J. Blus, C. J. Henny, D. J. Hoffman, L. Sileo and D. J. Audet, Ecotoxicology, 1999, 8, 125-132.

18 S. M. Strom, K. A. Patnode, J. A. Langenberg, B. L. Bodenstein and A. M. Scheuhammer, Arch. Environ. Contam. Toxicol., 2005, 49, 396-402.

19 D. H. Nam and D. P. Lee, Sci. Total Environ., 2006, 366, 682-687.

20 D. Peakall and J. Burger, Ecotoxicol. Environ. Saf., 2003, 56, 110-121.

21 J. Burger and M. Gochfeld, Ecotoxicol. Environ. Saf., 2004, 57, 136144.

22 J. Burger, Toxicol. Sci., 1998, 43, 155-160.

23 T. Dauwe, B. Lieven, J. Ellen, P. Rianne, B. Ronny and E. Marcel, Ecological Indicators, 2002, 1, 227-234.

24 G. M. Donaldson and B. M. Braune, Arch. Environ. Contam. Toxicol., 1999, 37, 110-114.

25 J. Burger and M. Gochfeld, Environ. Res., 2004, 94, 336-343.

26 J. Burger, Rev. Environ. Toxicol., 1993, 5, 203-311.

27 T. Dauwe, L. Bervoets, R. Blust, R. Pinxten and M. Eens, Belg. J. Zool., 1999, 129, 439-447.

28 S. S. Shapiro, M. B. Wilk and H. J. Chen, J. Am. Stat. Assoc., 1968, 63, 1343-1372.

29 M. B. Brown and A. B. Forsythe, J. Am. Stat. Assoc., 1974, 69, 264 267.

30 Student, Biometrika, 1908, 6, 1-25.

31 H. B. Mann and D. R. Whitney, Ann. Math. Stat., 1947, 18, 50-60.

32 F. D. Cid, M. Jofré, N. Navarro Becerra, N. Rodríguez, R. I. Antón and E. Caviedes-Vidal, Acta Toxicol. Argent., 2003, 11, 37-38.

33 Secretaría de Energía, Disposición 285/98, Subsecretaría de Combustibles, República de la Argentina. 1998.

34 T. Dauwe, E. Janssens, L. Bervoets, R. Blust and M. Eens, Arch. Environ. Contam. Toxicol., 2005, 49, 249-256.

35 K. Saeki, Y. Okabe, E.-Y. Kim, S. Tanabe, M. Fukuda and R. Tatsukawa, Environ. Pollut., 2000, 108, 249-255.

36 K. M. Swaileh and R. Sansur, J. Environ. Monit., 2006, 8, 209-213.

37 D. H. Nam, Y. Anan, T. Ikemoto, Y. Okabe, E. Y. Kim, A. Subramanian, K. Saeki and S. Tanabe, Environ. Pollut., 2005, 134, 503-514.

38 C. Wenzel, D. Adelung and H. Theede, Sci. Total Environ., 1996, 193, $13-26$.

39 T. M. Ansari, I. L. Marr and N. Tariq, J. Applied Sci., 2004, 4, 1-20.

40 J. Burger and M. Gochfeld, Arch. Environ. Contam. Toxicol., 2000, 38, 254-259.
41 J. Burger, Environ. Res., 2002, 90, 33-39.

42 L. J. Blus, C. J. Henny, D. J. Hoffman and R. A. Grove, Environ. Pollut., 1995, 89, 311-318.

43 L. A. Lewis, Arch. Environ. Contam. Toxicol., 2001, V41, 208-214.

44 R. Dietz, F. Riget, M. Cleemann, A. Aarkrog, P. Johansen and J. C. Hansen, Sci. Total Environ., 2000, 245, 221-231.

45 A. M. Scheuhammer, Environ. Pollut., 1987, 46, 263-295.

46 P. M. Walsh, in Heavy metals in the marine environment, ed. R. Furness and P. Rainbow, Boca Raton, FL: CRC Press, 1990, pp. 183-204.

47 J. Burger, R. Bowman, G. E. Woolfenden and M. Gochfeld, Sci. Total Environ., 2004, 328, 185-193.

48 P. N. Ferns and J. I. Anderson, Environ. Pollut., 1997, 96, 35-42.

49 R. Mateo, M. Taggart and A. A. Meharg, Environ. Pollut., 2003, 126, $107-114$.

50 D. H. Nam, Y. Anan, T. Ikemoto and S. Tanabe, Mar. Pollut. Bull., 2005, 50, 1347-1362.

51 K. LeJeune, T. Podrabsky, J. Lipton, D. Cacela, A. Maest, D. Beltman, Report of Injury Assessment and Injury Determination: Coeur d'Alene Basin Natural Resource Damage Assessment, U.S. Fish and Wildlife Service, U.S. Forest Service, and the Coeur d'Alene Tribe, Stratus Consulting, Inc. (Stratus), 2000.

52 D. H. Nam and D. P. Lee, Sci. Total Environ., 2006, 357, 288-295.

53 D. J. Pain, in Environmental Contaminants in Wildlife: Interpreting Tissue Concentrations, ed. W. N. Beyer, G. H. Heinz, A. W. Redmon-Norwood, Boca Raton, FL: Lewis Publishers, 1996, pp. 251-64.

54 J. C. Franson, in Environmental Contaminants in Wildlife: Interpreting Tissue Concentrations, ed. W. N. Beyer, G. H. Heinz, A. W. RedmonNorwood, Boca Raton, FL: Lewis Publishers, 1996, pp. 265-79.

55 G. D. Johnson, D. J. Audet, J. W. Kern, L. J. LeCaptain, M. D. Strickland, D. J. Hoffman and L. L. McDonald, Environ. Toxicol. Chem., 1999, 18, 1190-1194.

56 W. N. Beyer, J. Dalgarn, S. Dudding, J. B. French, R. Mateo, J. Miesner, L. Sileo and J. Spann, Arch. Environ. Contam. Toxicol., 2004, 48, 108-117.

57 V. Baruš, F. Tenora, S. Kraèmar and M. Prokes, Folia Parasitol., $2001,48,77-78$.

58 K. A. King and E. Cromartie, Colonial Waterbirds, 1986, 9, 90-94.

59 M. Custer, R. Roy, M. Wilson, T. Adomato, J. Winckel, An Investigation of Selenium, Mercury, and Lead Concentrations in Sediment and Biota from Maxwell National Wildlife Refuge, Colfax County, New Mexico. U.S. Department of the Interior, Fish and Wildlife Service, New Mexico Ecological Services Field Office, 1993.

60 T. W. Custer, C. M. Custer, R. K. Hines and D. W. Sparks, Environ. Pollut., 2000, 110, 469-482.

61 L. M. Hernandez, B. Gomara, M. Fernandez, B. Jimenez, M. J. Gonzalez, R. Baos, F. Hiraldo, M. Ferrer, V. Benito, M. A. Suner, V. Devesa, O. Munoz and R. Montoro, Sci. Total Environ., 1999, 242, 293-308.

62 F. D. Cid and E. Caviedes-Vidal, Atual. Ornitol., 2005, 125, 10-18.

63 T. Narosky and D. Yzurieta, Guía para la Identificación de las Aves de Argentina y Uruguay, ed. Vazquez Mazzini, Editorial Vazquez Mazzini, Buenos Aires, 2003, pp. 348. 